\title{
INFLUENCE OF BODY WEIGHT/AGE ON THE FOOD INTAKE, GROWTH AND CONVERSION EFFICIENCY OF GAMBUSIA AFFINIS
}

\author{
KATRE SHAKUNTALA \& S. RAVICHANDRA REDDY \\ Department of Zoology, Bangalore University, Bangalore 56000 , South India.
}

Received October 7, 1976

Keywords: body weight, age, food conversion in fish.

\begin{abstract}
On a restricted food supply of Tubifex tubifex $(2 \mathrm{~h} /$ day) the fish consumed only $69.5 \mathrm{mg}$ dry food $/ \mathrm{g}$ live fish/day and grew only to $25.6 \mathrm{mg}$ live body weight by the zoth day of it's age, while those fed ad libitum consumed $94.7 \mathrm{mg} / \mathrm{g} /$ day and attained a body weight of $125.9 \mathrm{mg}$ live weight by the 30 th day. Conversion efficiency $\left(K_{1}\right)$ averaged to $8.3 \%$ in the former and $\mathrm{I} 4.1 \%$ in the latter series, throughout the 30 day experimental period.

Feeding rate of the test series fed individually and at ad libitum, decreased from $780 \mathrm{mg}$ dry food/g dry fish/day for a fish weighing $4 \mathrm{mg}$ dry weight to $180 \mathrm{mg} / \mathrm{g} /$ day for one weighing $4 \mathrm{I} \mathrm{mg}$, exhibiting a $\log -\log$ relationship to the body weight $(Y=2.2014-$ $0.5639 \mathrm{X})$. Growth rate also decreased as a $\log -\log$ function with increasing body weight $(\mathrm{Y}=1.2309-0.4384 \mathrm{X})$.
\end{abstract}

\section{Introduction}

Experimental determinations of food intake, growth and conversion efficiency are known to offer important clues with regard to the ecological success of any organism (Kinne, 197I). These sequential parameters may be affected by environmental and/or endogenous factors (Pandian, 1975) and the endogenous factors like body weight/age are known to modify the conversion efficiency of fish (Gerking, 1952, 1971; Staples \& Nomura, 1976; Gerald, 1976). As a successful biological agent of mos* quito control, the larvivorous fish Gambusia affinis has been repeatedly introduced in various types of freshwater habitats (Gerberich \& Liard, 1966), where the fish has survived well even under adverse environmental conditions (Goodyear et al., 1972; Maglio \& Rosen, I 969). The present paper describes the influence of body weight/age

Dr. W. Junk b.v. Publishers - The Hague, The Netherlands on the food intake, growth and conversion efficiency of G. affinis.

\section{Material and methods}

Gestating females of Gambusia affinis were collected from a local fish farm and reared individually in battery jars containing aerated freshwater. To minimise the genetic variation, the 60 to 180 young ones born of a single gestating female were used for each experimental series.

Test individuals of G. affinis were fed on restricted $(2 \mathrm{~h} /$ day) or unrestricted (ad libitum) diet of the oligocheate worms Tubifex tubifex from the first day of their birth. Sex differentiation in G. affinis occurs by 30 days of age and involves disparity in the food intake and growth between the sexes (see Love, 1970; Katre, 1976). Hence, feeding experiments were discontinued after 30 days. During the thirty days experiment, at selected intervals, the levels of the following parameters were estimated:

Food intake was determined by subtracting the dry weight of uneaten food from the dry weight of daily food provided and expressed as mg dry food eaten/fish/day; feeding rate was calculated as mg dry food consumed/g live fish/day; growth as the gain in mg dry weight/fish/ day and conversion efficiency $\left(K_{l}\right)$ as a percentage of food consumed.

\section{Results}

On a restricted diet ( $2 \mathrm{~h} /$ day) food intake increased from $0.9 \mathrm{mg} /$ day for an individual weighing $1 \mathrm{I} .0 \mathrm{mg}$ on the 9 th day of it's age to $1.8 \mathrm{mg}$ /day for a fish weighing $26.0 \mathrm{mg}$ 
Table 1. Gambusia affinis: Effects of body weight and age on food intake, growth and conversion efficiency. Each value represents the average performance of 10 individuals reared on a restricted supply $(2 \mathrm{~h} / \mathrm{day})$ of Tubifex tubifex.

\begin{tabular}{|c|c|c|c|c|c|}
\hline $\begin{array}{l}\text { Age of } \\
\text { fish } \\
\text { (day) }\end{array}$ & $\begin{array}{l}\text { Live body } \\
\text { weight of fish } \\
\text { (mg) }\end{array}$ & $\begin{array}{l}\text { Food intake } \\
\text { (mg dry food/ } \\
\text { fish/day) }\end{array}$ & $\begin{array}{l}\text { Feeding rate } \\
\text { (mg dry food/g } \\
\text { live fish/day) }\end{array}$ & $\begin{array}{c}\text { Growth } \\
\text { (gain in mg dry } \\
\text { weight/fish/day) }\end{array}$ & $\begin{array}{l}\text { Conversion } \\
\text { efficiency } \\
\left(\mathrm{K}_{1}\right)(\%)\end{array}$ \\
\hline 9 & $\begin{array}{l}11.3 \\
\pm 3.25\end{array}$ & $\begin{array}{l}0.87 \\
\quad \pm 0.08\end{array}$ & $\begin{array}{l}79.5 \\
\quad \pm 4.32\end{array}$ & $\begin{array}{l}0.08 \\
\pm 0.007\end{array}$ & $\begin{array}{l}8.69 \\
\pm 0.46\end{array}$ \\
\hline 15 & $\begin{array}{l}17.3 \\
\pm 0.87\end{array}$ & $\begin{array}{l}1.12 \\
\pm 0.15\end{array}$ & $\begin{array}{l}64.7 \\
\quad \pm 2.82\end{array}$ & $\begin{array}{l}0.09 \\
\pm 0.003\end{array}$ & $\begin{array}{l}8.30 \\
\pm 0.59\end{array}$ \\
\hline 22 & $\begin{array}{l}18.8 \\
\quad \pm 0.82\end{array}$ & $\begin{array}{l}1.06 \\
\pm 0.05\end{array}$ & $\begin{array}{l}68.4 \\
\quad \pm 2.44\end{array}$ & $\begin{array}{l}0.09 \\
\pm 0.003\end{array}$ & $\begin{array}{l}8.77 \\
\pm 0.81\end{array}$ \\
\hline 30 & $\begin{array}{l}25.6 \\
\quad \pm 5.25\end{array}$ & $\begin{array}{l}1.78 \\
\pm 0.32\end{array}$ & $\begin{array}{l}69.5 \\
\quad \pm 3.42\end{array}$ & $\begin{array}{l}0.13 \\
\pm 0.050\end{array}$ & $\begin{array}{l}7.24 \\
\pm 0.50\end{array}$ \\
\hline
\end{tabular}

on the 3oth day (Table I). The corresponding values for growth were 0.08 and $0.13 \mathrm{mg} /$ day. On the other hand conversion efficiency remained more or less constant at about $8.3 \%$ throughout the 30 day experiment. This conversion efficiency showed a slight decrease to $7.2 \%$ on the 3oth day and might have decreased further beyond this age/body weight (Raghuraman, 1972).

Food intake is known to be dependent on the mode of presentation of food and ideally the fish should be provided with unlimited opportunity to feed (Brett, I971). When the food supply of Gambusia affinis was thus unrestricted (ad libitum), the daily food intake showed an increase from $3.3 \mathrm{mg}$ on the 9th day (20.1 mg body weight) to $7.1 \mathrm{mg}$ on the 30 th day (I $25.9 \mathrm{mg}$ body weight; Table 2); daily growth increased from 0.48 to $0.95 \mathrm{mg}$ in the corresponding period. Conversion efficiency however was apparently constant ( $14.1 \%$ ) but was markedly higher than when the food was restricted (Table $\mathrm{I}$ ). It is evident from Tables 1 and 2 that at any interval of age of $G$. affinis, growth depends on the level of food intake, and higher conversion efficiency is exhibited by the fish when the food supply is unlimited. Average feeding rate was also higher when there was unlimited food supply $(94.7 \mathrm{mg} / \mathrm{g}$ fish/day) than when it was limited to $2 \mathrm{~h} /$ day $) 70.5 \mathrm{mg} / \mathrm{g}$ fish/day). This indicates that growth and conversion efficiency are dependent on food intake.

\section{Discussion}

The IBP scheme of energy balance (Petrusewicz \& Macfadyen, 1970) for a fish may be represented by the following equation:

$$
C=P+R+F+U
$$

Table 2. Gambusia affinis: Effects of body weight and age on food intake, growth and conversion efficiency. Each value represents the average performance of 10 individuals reared on an ad libitum diet of Tubifex tubifex.

\begin{tabular}{|c|c|c|c|c|c|}
\hline $\begin{array}{l}\text { Age of } \\
\text { fish } \\
\text { (day) }\end{array}$ & $\begin{array}{c}\text { Live body } \\
\text { weight of fish } \\
\text { (mg) }\end{array}$ & $\begin{array}{l}\text { Food intake } \\
\text { (mg dry food/ } \\
\text { fish/day) }\end{array}$ & $\begin{array}{l}\text { Feeding rate } \\
\text { (mg dry food/g } \\
\text { live fish/day) }\end{array}$ & $\begin{array}{c}\text { Growth } \\
\text { (gain in mg dry } \\
\text { weight/fish/day) }\end{array}$ & $\begin{array}{l}\text { Conversion } \\
\text { efficiency } \\
\left(\mathrm{K}_{1}\right)(\%)\end{array}$ \\
\hline 9 & $\begin{array}{l}20.1 \\
\quad \pm 4.35\end{array}$ & $\begin{array}{l}3.28 \\
\pm 0.05\end{array}$ & $\begin{array}{l}163.2 \\
\pm 12.48\end{array}$ & $\begin{array}{l}0.48 \\
\pm 0.056\end{array}$ & $\begin{array}{l}14.4 \\
\pm 0.85\end{array}$ \\
\hline 15 & $\begin{array}{l}37.7 \\
\quad \pm 5.60\end{array}$ & $\begin{array}{l}4.50 \\
\pm 0.07\end{array}$ & $\begin{array}{l}106.1 \\
\pm 11.57\end{array}$ & $\begin{array}{l}0.64 \\
\pm 0.090\end{array}$ & $\begin{array}{l}14.2 \\
\pm 0.76\end{array}$ \\
\hline 22 & $\begin{array}{l}98.9 \\
\pm 8.20\end{array}$ & $\begin{array}{l}5.25 \\
\pm 0.22\end{array}$ & $\begin{array}{l}53.1 \\
\pm 3.98\end{array}$ & $\begin{array}{l}0.76 \\
\pm 0.080\end{array}$ & $\begin{array}{l}14.3 \\
\pm 0.94\end{array}$ \\
\hline 30 & $\begin{array}{l}125.9 \\
\pm 11.36\end{array}$ & $\begin{array}{l}7.10 \\
\pm 0.45\end{array}$ & $\begin{array}{l}56.3 \\
4.32\end{array}$ & $\begin{array}{l}0.95 \\
\pm 0.098\end{array}$ & $\begin{array}{l}13.3 \\
\pm 0.50\end{array}$ \\
\hline
\end{tabular}


where $C$ is the enrgy (food) consumed, $P$ is the growth, $R$ the energy loss as heat due to metabolism (estimated from oxygen uptake), $F$ the faeces and $U$ the urine excreted by the fish. Large number of earlier publications have established the fact that in fishes, absorption efficiency, which has a bearing on the $\mathrm{F}$, does not signifi- cantly vary as a function of body weight (Gerking, I952; Pandian, 1967a), quantity of food (Gerking, 1955; Davies, 1963; Pandian, I 967c), quality of food (Pandian, 1967b) and temperature (Menzel, 1960; Hari Sethi, I 970). Therefore any factor that alters either the $\mathrm{C}$, the $\mathrm{P}$ and/or the $\mathrm{R}$, will necessarily influence the one which is not modified.

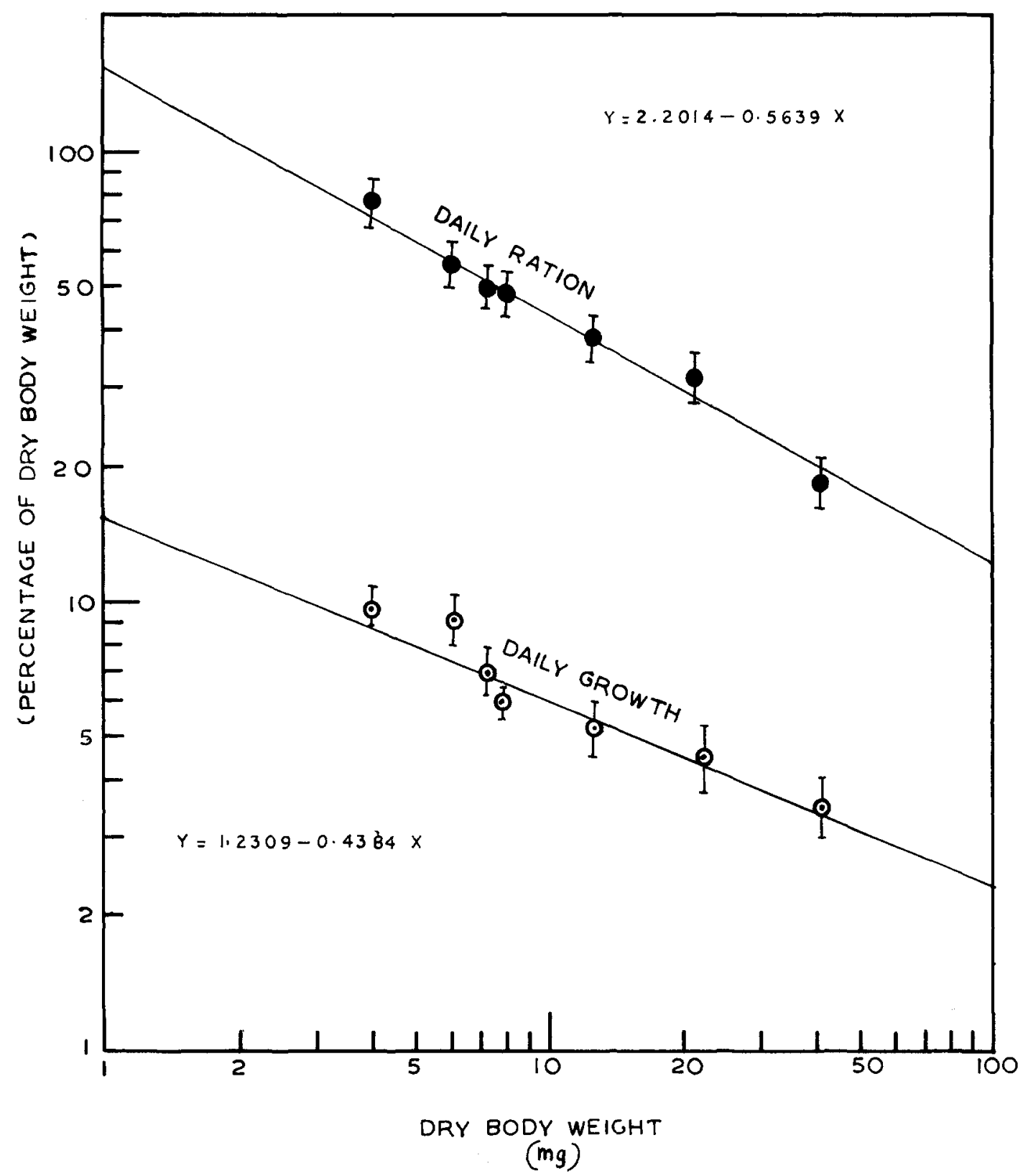

Fig. I. Gambusia affinis: Daily ration and growth (expressed as percentages of dry body weights) as functions of body weight of fish fed on Tubifex tubifex, under optimum laboratory conditions (fish reared individually in freshwater at $25 \pm 1^{\circ} \mathrm{C}$ and fed ad libitum). 
The C of Gambusia affinis of different body weights fed at optimum laboratory conditions (individual values obtained from the mean values given in Table 2), decreased as a $\log -\log$ function of the dry body weight from $78 \%$ body weight for the $4 \mathrm{mg} \mathrm{G}$. affinis to $18 \%$ body weight for a $4 \mathrm{I} \mathrm{mg} \mathrm{fish} \mathrm{(Fig.} \mathrm{I).} \mathrm{A} \mathrm{similar} \mathrm{log-log} \mathrm{relationship} \mathrm{has}$ also been reported for Onchorhynchus nerka (Brett, 1971), in which the decrease is from $17 \%$ body weight for a $4 \mathrm{~g}$ fish to $4.3 \%$ body weight for a $216 \mathrm{~g}$ fish. The values obtained in the present study cannot be compared with those of Brett (I97I) for O. nerka or Davis and Warren (1968) for O. tshawytscha due to the large differences in the body weights of the test individuals used in the experiments. However, the value of the $\mathrm{C}$ obtained for a $\mathrm{I} 6$ $\mathrm{mg}$ live G. affinis ( $78 \%$ body weight) is comparable to that obtained by Krivobok (1953) for the young wild carps (Cyprinus carpio) of $15 \mathrm{mg}$ live weight ( $54 \%$ body weight). On the whole, the $C$ values obtained for $G$. affinis in the present study are rather high when compared to those obtained by Karzinkin (1952) for either the young inconnu (Stendus sp.) or the young sturgeon (Acipenser guildenstädti) of the comparable body weights (see Winberg, 1960). Winberg (1960) computed that for a fish weighing $100 \mathrm{mg}$ live weight, the $\mathrm{C}$ would be 18 or $35 \%$ body weight, for fish with a $P\left(K_{1}\right)$ efficiency of 16 or 48 respectively. A corresponding sized $G$. affinis where the $\mathrm{K}_{1}$ during the present experiment never exceeded $14.4 \%$ (Table, 2), yielded the $\mathrm{C}$ value of $31.40 \%$ body weight per day (note: The water content of Tubifex worms used during the present experiment averaged to $83.6 \%$ of the live weight of the worms). Based on the oxygen consumption values, Winberg (1960; I96I) reported that in viviparous Cyprinodont fishes which are small in size, the $\mathrm{R}$ is low and decreases more than usual with increase in weight of the body. The high values obtained for the $\mathrm{C}$ in the cyprinodont fish $G$. affinis of body weights ranging from 4 to 8 mg dry weights suggest that the $\mathrm{R}$ may still be high. The $\mathrm{C}$ however, decreases with increasing body weights at the rate of $1.8 \%$ body weight for every $10 \mathrm{mg}$ increase in the dry body weight of the fish; although, the $P$ value decreases as a log-log function per se (Fig. I) the proportionate decrease in the $R$ is not as high as in $C$, so that after a particular body weight (maximum final weight of the species) is reached, growth of fish ceases (see Parker \& Larkin, I959; Brett, 1970).

Pandian (1967a) has considered that body weight of the fish approximately represents the age of the fish. The results obtained for Gambusia affinis lead us to conclude that these two parameters need not always be representing each other. For instance, an individual of $20 \mathrm{mg}$ body weight, on a restricted food supply exhibited a feeding rate of only $68 \mathrm{mg} / \mathrm{g}$ fish/day at the age of 22 days, but a fish of the same body weight on unrestricted food supply exhibited a higher feeding rate of $163 \mathrm{mg} / \mathrm{g}$ fish/day by the age of 9 days. Similarly, a 5 day old $G$. affinis on a restricted food supply and a lower feeding rate of 65 $\mathrm{mg} / \mathrm{g} /$ day weighed only $17 \mathrm{mg}$ while a fish of the same age, on an unrestricted food supply, by virtue of its high feeding rate $(106 \mathrm{mg} / \mathrm{g} /$ day), weighed $38 \mathrm{mg}$ (Tables I \& 2). However, when the fish was exposed to the same set of environmental conditions, especially the availability of food, there was some correlation between the body weight and the age as indicated by the minor deviations from the mean values given in the tables. It may therefore be suggested that, while conducting laboratory experiments on fish, especially during its growth phase, both body weight as well as age of the individuals must be considered rather than any one of these parameters only or else the individuals must be collected from a single population, living in the same set of environmental conditions.

\section{References}

Brett, J. R. 1970. Fish-The energy cost of living. In: Marine aquaculture pp. 37-52. Ed. W. J. Mc Neil, Oregon state University press

Brett, J. R. 197I. Satiation time, appetite and maximum food intake of sockeye salmon (Oncorhynchus nerka). J. Fish. Res. Bd. Canada. 28, 409-4I 5 .

Davis, G. E. \& Warren, C. E. 1968. Estimation of food consumption rates. In: IBP methods of assessment of fish production in freshwater. Ed. W. E. Ricker, Oxford, Blackwell Scientific publications, pp. 204-225

Davies, P. M. C. I 963. Food input and energy extraction efficiency in Carassius auratus. Nature, 198 (488I), 707.

Gerald, V. M. I976. The effect of size on the consumption, absorption and conversion of food in Ophiocephalus punctatus Bloch. Hydrobiologia, 49 (I), 66-77.

Gerberich, J. B. \& Laird, M. 1966. An annotated bibliography of papers related to the control of mosquitoes by the use of fish. WHO/Mal/66-562.

Gerking, S. D. I 952 . The protein metabolism of the sunfishes of different ages. Physiol. Zool., 25, 358-372.

Gerking, S. D. 1955. Influence of rate of feeding on body composition and protein metabolism of blue gill sunfish. Physiol. Zool., 28, 267-282.

Gerking, S. D. 197 I. Influence of rate of feeding and body weight on protein metabolism of bluegill sunfish. Physiol. Zool., 44, 9-I9.

Goodyear, C. P., Boyd, C. E. \& Beyers, R. J. 1972. Relationships between primary productivity and mosquitofish (Gambusia affinis) production in large microcosms. Limnol. Oceanogr., I 7, 445-45o. 
Hari Sethi, S. 1970. Temperature and bioenergetics of Cichlasoma bimaculatus. Ph. D. Thesis, Oregon University.

Karzinkin, G. S. I952. Foundations of the biological productivity of waters. Pishchepromizdat, Moscow.

Katre, S. 1976. Effect of feeding level on the rate and efficiency of food conversion in the cyprinodont fish Gambusia affinis (In press).

Kinne, O. I960. Growth, food intake and food conversion in a euryplastic fish exposed to different temperatures and salinities. Physiol. Zool., 33, 288-3I 7.

Kinne, O. 1971. Marine Ecology. Vol. I: Environmental factors part 2. pp. 683-1 244 London, Wiley Interscience.

Krivobok, M. M. I953. Utilization of food by young wild carp in the Azovo-Dolgii hatchery and rearing station. Trudy. VNIRO, 24, 102-II6.

Love, M. R. 1970. The chemical Biology of Fishes. London, Academic press. pp. 547 .

Maglio, V. J. \& Rosen, D. E. 1969. Changing preference for substrate colour by reproductively active mosquito-fish Gambusia affinis (Baird and Girard) (Poecillidae, Atheriniformes). American Museum, Novitates. No. 2397.

Menzel, D. W. 1960. Utilization of food by a Bermuda reef fish, Epinephelus guttatus J. Cons. perm. int. Explor. Mer., 25, 216222.

Pandian, T. J. 1967a. Intake, digestion, absorption and conversion of food in the fishes Megalops cyprinoides and Ophicephalus striatus. Mar. Biol., I, I6-32.

Pandian, T. J. I $967 \mathrm{~b}$. Transformation of food in the Megalops cyprinoides. I. Influence of quality of food. Mar. Biol., I, 60-64.

Pandian, T. J. 1967c. Transformation of food in the fish Megalops cyprinoides 2. Influence of quantity of food. Mar. Biol., I, I07-109.

Pandian, T. J. 1975. Mechanisms of Heterotrophy, In: Marine Ecology Vol. II, Part I, Ed. by O. Kinne. pp. 6I-2I2, London. John Wiley and Sons.

Parker, R. R. \& Larkin, P. A. 1959. A concept of growth in fishes. J. Fish. Res. Bd. Canada, 16, 72 I-745.

Petrusewicz, K. \& Macfadyen, A. I970. Productivity of terrestrial animals. IBP Hand book No. I3, Blackwell Scientific Publications Oxford, pp. I90.

Raghuraman, R. I972. Effect of body weight on intake and conversion of food in the fish Rasbora daniconius. Curr. Sci. 42 (I), 24-25.

Staples, D. J. \& Nomura, M. 1976. Influence of body size and food ration on the energy budget of rainbow trout Salmo gairdnerii Richardson. J. Fish. Biol. 9 (I), 29-43.

Winberg, G. G. 1960. Rate of metabolism and food requirements of fishes. Fish. Res. Bd. Canada. Transl. Series. No. 194, pp. 202.

Winberg, G. G. 1961. New information on metabolic rate in fishes. Fish. Res. Bd. Canada, Transl. Series. No. 362, pp. I I. 